\title{
How Finnish Muslim Students Perceive and Deal with Religious and Cultural Difference: Negotiating Religious Tradition with Modern Liberal and Postmodern Ideals
}

\author{
Inkeri Rissanen \\ Faculty of Theology, University of Helsink, 00014 Helsinki, Finland \\ Correspondence should be addressed to Inkeri Rissanen, inkeri.rissanen@helsinki.fi
}

Received 21 February 2012; Accepted 18 June 2012

Academic Editor: Kirsi Tirri

Copyright ( $) 2012$ Inkeri Rissanen. This is an open access article distributed under the Creative Commons Attribution License, which permits unrestricted use, distribution, and reproduction in any medium, provided the original work is properly cited.

\begin{abstract}
This paper presents the results of a qualitative case study examining Muslim students' ways of perceiving and dealing with difference. The study is motivated by the need, expressed in previous literature, to achieve more elaborate comprehension of the relation between tolerance and religiosity. Deeper understanding of these dynamics is pursued by concentrating on one specific group and context-Muslim youngsters in Finland. The students' negotiations between different cultural and ideological sources of understanding difference and tolerance will be elaborated and discussed. These negotiations reflect the special challenges encountered when dealing with religious difference.
\end{abstract}

\section{Introduction}

Since 9/11 scholars from many fields have been showing interest in religion and its relation to xenophobia and violence [1-4]. While religions are factors in many conflicts, they also contribute to dialogue and peaceful coexistence. There is a lot of empirical support for the hypothesis that religiosity correlates negatively with deviant behaviour (see [2]). On the other hand, there are also studies showing how religiosity increases intolerance, negative intergroup attitudes, or xenophobia $[3,5]$. These ambiguities might result from the deficiencies in operationalizing religiosity and tolerance found in many studies. Due to the diversity of religious cognition and experience, as well as the complexity of the concept of tolerance, many studies have drawn simplistic conclusions about their relationship $[3,6]$. Furthermore, religions are often considered subordinate to cultural diversity and the special challenges in dealing with religious differences left unnoticed. These confusions have motivated this study, the purpose of which is to gain deeper understanding of the dynamics of dealing with religious and cultural difference by concentrating on one specific group and context-Muslim students in Finland.

Tolerance, religiosity, and diversity are understood in distinct ways in different discourses and ideological frameworks affecting religious education. Confessional religious education aiming at religious socialisation is grounded on the ideals of religious traditions, but it has been challenged by liberal and postmodern paradigms. However, often these approaches overlap, which is also the case in Finland. In order to be able to elaborate the multidimensionality of the dynamics of dealing with difference, this study examines the ways in which the students' ideals and ways of perceiving and dealing with difference have been affected by these overlapping educational discourses that draw from liberalism, postmodernism, and religious tradition.

The liberal paradigm of religious education is the result of questioning the traditional confessional models. Confessional education, which means enculturation to the beliefs, values, and practices of religious tradition, became problematic in the light of the liberal ideals of autonomy and tolerance, which relate to reducing beliefs to matters of subjective opinion and questioning religious education based on exclusive truth claims [7]. In the liberal framework, tolerance is regarded as a necessary ground for individuality, autonomy, and freedom, that is, the core values of liberalism that demand respect for all individuals. However, difference must be balanced with unity, which sometimes also leads to modifying difference so that it fits into the demand for unity $[8,9]$. In modern liberal states this ideal of social unity 
has sometimes resulted in understanding equality as cultural assimilation. Difference is tolerated only in the private sphere and unity is equated with homogeneity. For example, uncritical acceptance of dogma based on authority or revelation is unwelcome, which makes it hard to accommodate deep forms of difference, such as passionate religious identity: this explains why Muslims have become "the critical case of multiculturalism" in many liberal societies $[10,11]$.

The liberal paradigm is nowadays extensively criticised. Religious education based on these liberal ideals is in risk of misrepresenting how religions understand themselves and creating a conflict of values. For example, some fundamentalist Christians regard liberal education in its promotion of tolerance as indoctrination and as a threat to their cultural integrity [12]. According to postmodern critiques, in a liberal framework only those willing to accept liberal values are tolerated. The liberal principles of freedom and tolerance have become ends in themselves and tolerance has developed into a closed worldview. Postmodernists have endeavoured to overcome these pitfalls of the liberal framework by accepting the diversity of local micronarratives and replacing objective knowledge with relativism and subjectivism [7]. In postmodernist approaches to religious education, the life world of the student becomes the center of attention and the focus is on the ideal that students should construct their own knowledge and spirituality [13]. Diversity is understood as enrichment and tolerance as the positive evaluation and true acceptance of others, not as a mere endurance of differences.

However, this approach can also be accused of departing from the self-understanding of religious traditions. A postmodern antirealistic way of understanding and celebrating difference as "all there is" leads to a concept of tolerance that requires renouncing the idea of one single truth or reduces questions of truth to matters of personal preference and is itself in danger of imposing a worldview that does not recognize radical forms of difference $[7,8]$. In a postmodern framework, religious difference is optimally dealt with in a dialogue that departs from religious exclusivism and requires that one is continuously able to change one's ownperceptions this is regarded as openness (see, e.g, [3]). The influence of this kind of postmodern paradigm can be observed in the concepts of European teenagers, who believe in the possibility of the peaceful coexistence of religions and declare their positivity towards religious diversity, but at the same time are critical of exclusive truth-claims and actually regard what is different as an obstacle to dialogue [14].

However, believing that the contradictions between one's own theories of truth and those held by others are irreconcilable does not have to be equated with intolerance: when there is a strong ideal of one truth, not demanding too much of tolerance is vital in order to facilitate peaceful coexistence without compelling religions to renounce their self-understanding [8]. Nevertheless, liberal educationalists fear that the dogmatic position of Islam with its absolute truth-claims leads to intolerance. The primacy of religious belief and the idea that one should not open religious beliefs to critical scrutiny creates a conflict with liberal educational ideals and entails indoctrination [15]. However, while holding on to exclusive truth-claims and ideas of universality, religions themselves can function as resources for tolerance. As long as Islam has existed, it has encountered other religions. Its basic teachings leave room for different interpretations concerning the position of other religions, and throughout history Muslims have adopted various attitudes towards non-Muslims. In the Qur'an, Jews and Christians are criticised, but also defined as "People of The Book" and thus given a protected status. Even though claims of universality are essential in Islam, the Qur'an also states that "there is no compulsion in religion" and encourages the respectful treatment of others $[16,17]$. Thus, tolerance in the Islamic framework is grounded on the ideas of freedom of religion and the equality of all human beings as creatures of God, which should lead to the respectful treatment of all peoples, despite the exclusivity and universality of religious truths. Schweitzer [18] introduces the possibility of pursuing tolerance in education by invoking the values related to tolerance within religious traditions and seeing them as "resources for tolerance." His arguments rest on findings according to which individualised faith does not engender tolerance. This makes it important to embrace the possibility of promoting tolerance from within the different religious traditions.

These different cultural sources of understanding diversity, tolerance, and religion also affect educational discourses in Finland. It is important to start paying attention to how different cultural paradigms affect students' ideals of dealing with difference, which is an unstudied area. Furthermore, there is lack of research on the ways in which young immigrant Muslims deal with difference. Researchers studying Muslim identities do not always take into account the rich variety of Muslims' own understandings of their identities or the effects of a particular cultural and political context on these identity processes [19]. In a similar manner, understanding the variety of Muslims' ways of dealing with difference requires departing from the perspectives of "official Islam" and taking into account the ways in which individuals have been influenced by other cultural sources. For these reasons, the objectives of this study are to analyse (1) how Finnish Muslim students perceive and deal with difference, and (2) how these perceptions reflect the ways in which a commitment to religious tradition and experiences of life are negotiated with influences from liberal and postmodern discourses. Even though there is a certain amount of ambiguity related to these paradigms and they often share features, in this article, they are used as analytical tools in order to increase understanding of the tensions related to the students' ways of dealing with difference.

\section{Finnish Context}

Finland differs from other European countries that have experienced Muslim immigration in that it has had a small Muslim population, the Turkish Tatars, for over a hundred years, but postwar immigration started as late as in the end of the 1980s. Nowadays, the Muslim population in Finland is ethnically mixed, with Somalis, Arabs, Kurds, Kosovo Albanians, Bosnians, and Turks as the largest groups. 
Approximately 0,8 percent of the Finnish population are Muslims, but the figure is somewhat higher in the area of Helsinki, where this study took place $[20,21]$.

Finland has long been regarded as quite a homogeneous nation, most of its population (roughly 80 percent) belonging to the Evangelic Lutheran Church. When awareness of this Islamic presence in Finland awoke in the 1990s, it was considered alien and threatening. Furthermore, Finland was coping with a recession, and Muslim immigrants have been very dependent on the Finnish welfare system due to the difficulties in integrating them into the Finnish labor market: this has hardened attitudes, and public opinion concerning Muslims is on the whole negative $[20,21]$. In this study, attention is also paid to how this position as a disadvantaged minority group and the fact that it is regarded by society as a whole as a social problem affects Muslim students' ways of dealing with difference.

However, efforts are being made to encourage mainstream Finnish opinion to be more sensitive to cultural and religious diversity. This study is part of a larger case study examining Islamic education in Finnish schools, and these educational policies reflect the ethos of Finland's multicultural policies. The positive aspects of religious freedom are emphasized, and students are granted the right to receive a religious education according to their own tradition if there are a sufficient number of them from that religious tradition living in the same area. In any event, confessional and liberal approaches overlap in the Finnish curriculum. The content and aims of religious education are not constructed according to the interests of religious communities, and religious observance in the classroom is prohibited. The development of the religious and cultural identities of the students is supported because this is regarded as an important means of enhancing their integration into Finnish society. This reflects the fact that the endeavour to integrate individuals has been the primary reason for granting collective cultural rights in Finland [22].

The purpose of religious education is to give students material for building their identity and worldview. In the core curriculum, religion is presented as subordinate to culture-respect for people who "think and believe in a different way" is developed by presenting different religions as variations of the religious "undercurrent influencing human culture" [23]. Thus, even though the curriculum puts an emphasis on religious traditions, presenting religions as cultural sources for students to individually draw from reflects influences from postmodern individualism. The postmodern ideal of celebrating difference is further strengthened by the common educational ethos according to which prejudices are dissolved and tolerance increased by understanding cultural diversity as a resource and a source of enrichment [22].

\section{Data and Methods}

The methodological design draws from educational ethnography in pursuing an understanding of a cultural phenomenon at school (see [24]). Many of the guiding principles of the study link it to the tradition of critical ethnography (see [25])-attempting to speak on behalf of the subjects of the study, paying attention to wider ideological processes affecting the microsocial details observed, and recognizing the critical ideas affecting the research process. The study is inductive in nature, but the interpretations have been influenced by the assumption that discourses on difference in school and in society are ideologically loaded.

In the wider case study examining Islamic education, of which this paper is a part, three courses of Islamic education in Finnish comprehensive and upper secondary schools, taught by experienced teachers, were observed. From those courses, 16 students that were willing to participate were interviewed. In these semistructured interviews, three main themes were discussed: the students' thoughts and experiences of (1) their own religion, (2) other religions and cultures, and (3) Islamic education. The interviews lasted from 25 to 45 minutes.

The students were first $(n=9)$ or second $(n=$ 7) generation immigrants from 8 different countries, aged between 13 and 19. They had all lived in Finland for at least seven years and were fluent speakers of Finnish. Five boys and eleven girls were interviewed-owing to a coincidence, there were only girls participating in one of the courses. All the students considered Islam as an important or very important part of their lives. Interviews were conducted in a school context during Islamic education lessons, which probably made the students feel that they were representing Islam to a Christian researcher and, at first, they seemed to endeavour to give what might be called the "right" answers. This, however, made it possible to observe the ways in which the different discourses on diversity and tolerance had influenced the students' understanding of ideal ways of dealing with difference.

The data was analysed by means of inductive qualitative content analysis. The variety of the students' concepts was elaborated without focusing on the profiles of individual students. Thus, the different ways of dealing with difference presented are not mutually exclusive but context dependent. All utterances relating to the research questions were extracted from the litterated data, condensed, and coded. In a circular process, these codes were grouped into subcategories and categories that were again revised by returning to the condensed meaning units. The main categories of analysis are represented in a compact, tabular form (Tables 1 and 2). The validity of the study is fostered by relying on multiple sources of data and substantiating the researcher's interpretations by presenting plenty of examples from the data.

\section{Results}

4.1. Students' Ways of Perceiving and Dealing with Religious and Cultural Difference as Influenced by Liberal Ideals. The students tended to declare that difference was not an issue (Table 1). For example, statements that emphasized the insignificance of the fact that people belong to different cultures and religions were grouped under this category. Some students eagerly argued that religion does not make 
TABLE 1: Ways of perceiving and dealing with difference related to the negotiation of liberal ideals.

\begin{tabular}{|c|c|c|c|}
\hline Difference is not an issue & $\begin{array}{l}\text { Difference is a problem-causing } \\
\text { matter }\end{array}$ & $\begin{array}{l}\text { A conformist way of dealing } \\
\text { with difference }\end{array}$ & $\begin{array}{l}\text { Dealing with difference by con- } \\
\text { centrating on oneself }\end{array}$ \\
\hline $\begin{array}{l}\text { (i) Difference is an insignificant } \\
\text { fact } \\
\text { (ii) Difference is a positive fact }\end{array}$ & $\begin{array}{l}\text { (i) Difference causes difficulties } \\
\text { in understanding others } \\
\text { (ii) Difference causes difficul- } \\
\text { ties in interacting with others } \\
\text { (iii) Difference is a complex } \\
\text { issue }\end{array}$ & $\begin{array}{l}\text { (i) Trying to avoid confronta- } \\
\text { tion } \\
\text { (ii) Adaptation } \\
\text { (iii) Dealing with difference by } \\
\text { concentrating on commonality, } \\
\text { equality, and togetherness }\end{array}$ & $\begin{array}{l}\text { (i) Adhering to one's own } \\
\text { religion } \\
\text { (ii) Representing one's } \\
\text { own religion }\end{array}$ \\
\hline
\end{tabular}

people different. There were reasons to interpret that these statements expressed an ideal of dealing with difference learned from liberal discourse-it should not be regarded as a problem. This ideal, however, had to be negotiated with experiences of life: as the discussions became deeper, critical attitudes and negative experiences often supplanted the neutral attitude that had initially been declared. A large majority of the meanings given to difference related to the perception that it was a problem-causing matter (Table 1). Difference was considered to cause various difficulties in human relations. In the following example, a student explains why she would rather live in Turkey than in Finland:

They would understand Muslims. Christians do not understand Muslims. It would be nicer to live in a country where there were more Muslims than Christians.

\section{Researcher: Why don't they understand Muslims? \\ Student: They can't think in the same way as Muslims. It's because Muslims think in a totally different way to Christians.}

Most of the students did not report having experienced major difficulties in living with religious and cultural diversity, but generally thought that difference causes fights, discrimination, and irritation. Even students who emphasized the easiness of being a Muslim in their own school and in Finland said it would be easier to get along with people in a Muslim country. Being a representative of a minority was regarded as a burdensome matter that caused practical difficulties and feelings of shame. Muslim youngsters tend to remain loyal to traditional Islamic values whilst western societies have become more liberal. Sexual ethics have become the main dividing line separating young Muslim from their non-Muslim peers [26]. The most troubling matter for the students of this study seemed to be the different conventions governing appropriateness which affected their friendships as alcohol and dating had become issues - this was pondered upon much more than the difficulties in practicing religion.

Liberal discourse emphasises tolerance because all people are equal, but often in a way that accepts dichotomy only within unity [8]. Possibly, the students' way of declaring the insignificance of difference was influenced by this ideal that, however, had to be negotiated with the difficulties they experienced. Furthermore, ideals from the liberal discourse could be seen in the students' comments that embraced conformist ways of dealing with difference (Table 1). Almost all the students expressed ideas that considered preserving harmony as the best way of dealing with difference: a defining feature of this category was the conceived importance of being careful not to do or say anything offensive. The idea that religious differences do not have to be exhibited or affect things was sometimes represented as an ideal, and seemed to be influenced by the liberal idea of confining differences to the private sphere. Most of the students had friends who were not Muslims, but this was often considered possible because they did not discuss religious differences.

Another conformist strategy of dealing with difference was adaptation. It related to, for example, modifying one's behavior when in the company of believers in another religion, as demonstrated by the following:

\section{Student (15-year-old girl): Well, with Muslims I'm like the way they are, and with members of other religions I try to be a little like them and behave how they do, but I mix my own religion to it [...] So that I wouldn't be peculiar but would fit in.}

Assimilation is a common response to having or being given a negative social identity [27]. In the negotiations of the students of this study, however, this ideal was more easily absorbed in the case of cultural aspects of difference, such as differences in behavior. Some students expressed their views about the importance of conforming to Finnish culture and criticized Muslims not willing to do so. However, when it came to differences between religious beliefs and doctrines, the dominant way of dealing with them was by ignoring such differences and concentrating on commonality either by referring to their similarities or with reference to people's equality. Students referred to the similarity of all religions, but mentioned only Christianity, Judaism, and Islam, which reflected the teachers' way of emphasizing these religions (see [28], in press). Positive statements concerning other religions often related to the idea of similarity in questions of truththe common belief in one God.

When asked about the differences, the students mentioned variations in the common denominators of the religious way of life, which were considered insignificant:

Researcher: What do you think of other religions?

Student (14-year-old boy): Well, they aren't different because Christians believe in God, but then there are different things. 


\section{Researcher: What do you think is the most important difference?}

\begin{abstract}
Student: The difference is that Muslims have a mosque while Christians have a church, and then there are different things like a priest and an imam, and stuff like that.
\end{abstract}

The most common reason given for seeing other religions as harmless was that they do not differ from Islam: in a way, similarity was regarded as a prerequisite for peaceful coexistence and was identified with equality. The students phrased this idea in such similar ways that the fact that they had learnt it by participating in the same educational discourse was evident. The teachers of Islamic education were themselves balancing between liberal educational aims and the need to preserve the self-understanding of Islam: this led them to emphasise tolerance as an Islamic virtue based on the commonality and similarity of Muslims with Christians and Jews [28]. However, the discourses in the lessons of Islamic education seemed to be affected by a liberal pressure for inclusivity, which also resulted in seeing similarities where they do not actually exist. This, however, was the case only in dealing with differences in religious beliefs and norms - diversity in behavioural conventions was more easily acknowledged and could also be dealt with by adapting. These observations further confirm perceptions that religious boundaries are more insurmountable in nature than those between cultural groups [29] and show how dealing with religious differences in a liberal framework is sometimes problematic.

However, the minority status of these Muslim students is also an important explanatory factor for their way dealing with difference in a conformist way. These students identified being Finnish with Christianity. Thus, when their differences with the Christian majority were suppressed, it was easier to be recognised as part of the Finnish majority, which promotes one's societal image and guarantees more power [30]. However, this kind of way of "capitalizing on commonality" also has certain pitfalls: in the situation of truly existing differences, the sense of similarity is difficult to sustain and might also increase the need to emphasise the positive distinctiveness of one's own group [30, 31]. This reflects the way in which the multiculturalism of liberal democracies draws minorities to negotiate between a separate identity and "usness," and often leads to minorities preferring a dual identity $[11,31]$. Thus, the students of this study also seemed to have to balance the conformist way of dealing with difference, influenced by liberal ideals, with a defensiveness about their religious identity. This was done, for example, by regarding group-boundaries as justifiers of difference. In itself the fact that people belong to different religions was regarded as contributing to orderliness and peaceful coexistence. If people know they belong to different religions, it is clear that they have differences and there is no need to find a consensus, or so one might conclude from the reasoning of this 16-year-old boy, who referred to his Christian friends:

\begin{abstract}
If they, for example, claim that Jesus is the son of your God, then we might begin opposing that by saying that Jesus is some kind of prophet in our religion. Then this leads to discord, but in the end we are like yeah, we have like different religions, so we could keep arguing the whole day, but (laughs) it's like different religions.
\end{abstract}

The students also guarded the boundaries between "us" and "others": one of the teachers spoke about the students' indignation when a non-Muslim teacher had greeted them according to Islamic conventions. From a social psychological perspective, the logic in the students' way of guarding their religious group boundaries is clear. The extent to which a person is recognised as a member of one's group always affects the evaluation of deviance: deviance is less likely to be regarded as a threat when there is less pressure for group uniformity and belonging to a different social category can be regarded as a valid explanation for differences [30]. Thus, the endeavours to combine liberal ideals with experiences of representing a minority religion led many of the students to deal with difference by concentrating on oneself (Table 1). Their primary concern seemed not to be how to get along with others but how to build and protect their own identity. In general, they disapproved of those who had "forgotten" Islam in Finland, but there were also those who spoke about their own growing distance from an Islamic way of lifeusually with the intention of changing this trend in the future. Remembering one's own religion was a salient factor in dealing with difference.

The students often felt a need to rationalize their commitment to Islam. Defensive attitudes were demonstrated when the students justified their commitment to traditional Islamic values by negatively stereotyping others with accusations of immorality: this can be interpreted as a strategy for enhancing collective self-esteem (see [32, 33]). Students considered Christians immoral and irresponsible, especially in their sexual and drinking behavior, and referred to Muslims as people of higher morality:

\section{Student (15-year-old girl): Muslims are, I don't know, reliable. But I think Christians, not all, but many of them, are not reliable and faithful.}

Furthermore, there was a strong intention to represent Islam to others correctly. Thus, dealing with difference by concentrating on oneself was connected to the experienced need to defend oneself against certain threats, such as cultural influences affecting Muslims in a diasporic situation, negative attitudes towards Islam resulting from media representations, and the pressure to conform to the liberal ideal of rational, autonomous, and private religiosity. They seemed to endeavour to emphasise the rationality and autonomy of their decision to commit to religious tradition, as demonstrated by this 16-year-old girl:

Researcher: What do you think of being a Muslim?

Student: I think it's great! I am very happy. I have not always taken for granted that I am a Muslim, 
I have considered all the other religions and stuff like that, but now I think this is an amazing religion. I do respect all the others but this religion is the right one, I think. I really am very content with this.

There is a general tendency among European Muslim adolescents to guard their religious identity by emphasizing Islam as a rational religion and a chosen way of life [34]. This kind of defensiveness, also observed in this study, could be interpreted as a counter reaction to the misrepresentation of religion in the liberal discourses of multicultural societies: religious revivalism often occurs and fundamentalism rises when believers fight against their belief that their religion is being disregarded and confined to the private sphere. There is a "born again" Islamic youth who want to base their thoughts and praxis straight on the Qur'an and sunna, and criticize the cultural practices associated with popular Islam in order to defend their understanding of the authenticity of Islam $[34,35]$. However, these identity processes can be interpreted to be influenced by the modern liberal ideals of individuality and autonomy: Muslim youth negotiate between tradition and individuality, as well as between contextual liberal and universalist fundamental Muslim identities by emphasizing Islamic identity as a matter of individual choice and Islam as a rational religion $[34,36]$.

4.2. Students' Ways of Dealing with Religious and Cultural Difference as Influenced by Post-Modern Ideals. Many of the students in this study quite strongly declared their positive attitudes towards religious and cultural difference, even though sometimes the only reason they could give for this attitude was that similarity should not be desirable. Thus, even though students declared that diversity was a value in itself, this concept was superficially internalized and seemed to reflect a learnt ideal, the roots of which can be traced to the postmodern discourse on diversity as enriching. However, there were also students who had internalised this ideal more deeply and could specify why they perceived difference as an opportunity (Table 2). Two students referred to the opportunity to express oneself through different religions and cultures. More common was the idea that difference makes it possible to learn about, and from, others, which related to the perceived importance of difference in preventing a dull, bland existence. However, the ideal of learning from other religions was expressed mainly as an opportunity for others to learn from Islam, which is demonstrated by the following example, in which the manner of denying the problems caused by difference is also evident:

One student (14-year-old boy) explains why he considers difference favourably: You see... in Islam, I guess these alcohol problems are a little better, so Christians can learn from it.

Researcher: Are there any other things that could be learned from Islam?

Student: Well, not doing evil things and stuff like that.

\begin{abstract}
Researcher: So what kinds of problems might be caused by the fact that people are so different?
\end{abstract}

Student: No kinds of problems.

Researcher: No problems at all?

\section{Student: No.}

In this way, students seemed to negotiate between the ideal of understanding diversity as a resource and their identification with a religious tradition that has ideas of moral absoluteness and superiority as its central feature. The same students who declared religious diversity in terms of an opportunity for religious autonomy and freedom also emphasised the importance of adhering to their own religion. They explained how the existence of different religions and cultures enhances the freedom of the individual by facilitating the opportunity to learn from, or to choose between, them, but for these students this actually meant that they could declare their Islamic identity as an autonomous decision. This can be interpreted as a way of reconciling a commitment to a religious tradition with the liberal ideal of autonomy as well as the postmodern ideal of constructing one's own religious identity.

The shallow understanding of tolerance and diversity as an enriching value that is common among European teenagers [14] was also apparent among the students of this study. Their superficial way of absorbing the postmodern ideal of celebrating difference later became evident when some students who had declared their positivity towards difference were actually inclined, in some respects, to adopt a resistant way of dealing with difference (Table 2). For example, they preferred to reduce difference, did not consider the problems caused by it to be solvable, and mistreated those who were different. Students who were inclined to a more relativistic religiosity very straightforwardly condemned those who "think their beliefs are better." Thus, it seemed that these students considered a resistant way of dealing with difference more appropriate when the differences were localised between inclusivists and exclusivists rather than between religions. This is reminiscent of the intolerance towards exclusive truth claims which was observed to be a common feature of European teenagers in the REDco project [14].

Among European Muslim youth, there are tendencies towards both the privatization and relativization of religious identities as well as islamization and normativization [34]. Increased individualization has brought with it a shift from obedience to individuality and the creation of an authentic self that comes with the idea of choosing tradition [37]. The students in this study seemed to be compelled to negotiate between the Islamic ideal of commitment to tradition and the postmodern individualistic and relativistic discourse on building religious identity according to one's own preferences. This implied individualizing "through Islam" rather than "from Islam" (see [38]). However, this is not always without contradictions, which was the case also in this study: the students emphasized the importance of being a good Muslim by obeying the unchangeable Islamic doctrines, 
TABLE 2: Ways of perceiving and dealing with difference related to the negotiation of post-modern ideals.

\begin{tabular}{llll}
\hline Difference is an opportunity & Difference is a threat & $\begin{array}{l}\text { An open and rewarding way of } \\
\text { dealing with difference }\end{array}$ & $\begin{array}{l}\text { Resistant ways of dealing with } \\
\text { difference }\end{array}$ \\
\hline $\begin{array}{llll}\text { (i) Difference is an opportunity } \\
\text { for learning }\end{array}$ & $\begin{array}{l}\text { (i) Difference is a threat to one's } \\
\text { own religion }\end{array}$ & $\begin{array}{l}\text { (i) Recognizing and pondering } \\
\text { (ii) Difference is an opportunity }\end{array}$ & $\begin{array}{l}\text { (ii) Difference is a threat to others } \\
\text { on difference }\end{array}$ \\
$\begin{array}{ll}\text { (iii) Difference is a threat to one's } \\
\text { for autonomy and self-expression deal with differ- } \\
\text { religious identity }\end{array}$ & $\begin{array}{l}\text { (iii) Interacting with others } \\
\text { ence }\end{array}$ & $\begin{array}{l}\text { (ii) Negative treatment of those } \\
\text { who are different }\end{array}$ \\
\hline
\end{tabular}

even though they at the same time embraced the idea of building ones religious identity autonomously by drawing from different religious traditions.

Nevertheless, even though combining religious commitment with the ideal of religious diversity as a possibility required certain acts of negotiation, in the case of cultural diversity these were not needed. The students associated culture with behavior and regionality and religion with faith and universality, and in the case of nonnormative differences that could be regarded as culture, the opportunity for learning was understood more reciprocally and the ideal of enrichment absorbed more naturally. However, the students of this study, who were committed to their religious tradition, had to negotiate the ideal of diversity as an enrichment with an understanding of religious difference as a threat (Table 2). Perceiving diversity as a threat related specifically to the diversity of religious beliefs and norms. In order to understand the dynamics of these perceptions, the exclusivity of Islamic truth-claims as well as the ideal of unity have to be taken into account. One of the students put it simply: religious diversity is an unfortunate thing, because there is only one God. The fact that the universal truth-claims held by religion eventually lead to perceiving other religions as distorting the truth also became evident in statements of the following kind:

\section{Student (14-year-old girl): In our religion it is a sin to situate Jesus by the side of God, but these Christians say that Jesus is the son of God. If we believe in that, it is a sin.}

However, associating religious difference with sin led to considering it as a threat not mainly to oneself but to others - the salvation of non-Muslims was considered during the observed lessons.

Disregarding the nature of religious differences in postmodern discourses can lead to defensiveness and the guarding of the autonomy of religions by putting an emphasis on the universality and absoluteness of religious truths, which lays the ground for fundamentalist reactions (see [39]). The students in this study seemed to be drawn to negotiate between relativistic discourses and the need to defend the authenticity and legitimacy of their tradition. However, perceiving diversity as a personal threat also related to the concrete situation of living as a member of a minority. The students brought out the difficulties in learning their religion, adhering to it, and resisting the attractions of a secular, often equated with a Christian, lifestyle. With no exception even those students who fluently participated in the postmodern and liberal discourses emphasizing individuality, freedom, and the celebration of diversity, regarded departing from the Muslim way of life as a danger. Even though the personal religiosity of the immigrant Muslim students in this study varied, religion was at the core of their group identity, having the capability of providing a sense of stability and continuity. This explains why influences from outside the group that damage the integrity of their religion are easily regarded as threatening [30, 40]. Furthermore, there is a strong ideal of unity in Islam, and when pressure towards uniformity increases, deviance is more likely to be regarded as a threat [30].

Thus, due to their disadvantaged position as a minority group in Finland as well as the ideal of unity in Islam, it might be possible that these Muslim youngsters' need for a social identity in the face of a perceived threat would outweigh the impact of education about tolerance (see [5]). Nevertheless, the ideals and experiences which this study categorised under an open and rewarding way of dealing with difference (Table 2) can be seen as a result of a negotiation between postmodern and religious ideals of dealing with difference. However, this category only included statements from some of the students. In the postmodern relativistic discourse on difference, openness is the ideal way of dealing with difference and it is defined as the capability to navigate between different cultural frameworks or to re-evaluate constantly one's religious views [3, 41]. However, the students in this study seemed to have absorbed the ideal of openness from the postmodern discourse, but interpreted it in a different way because of their need to reconcile it with their commitment to a religious tradition.

The students were interested in other religions, but this did not relate to understanding them as material for building one's own identity. The idea of knowing enough about others as a necessary way of coping with difference was commonly referred to. Even though for some students of this study familiarizing oneself with other religions in order to choose one's own beliefs seemed to represent the "right" way of dealing with difference, there were no signs of these students truly considering beliefs held by other religions, except for one 15-year-old boy from a multireligious family, who wanted to find out which religion really is right about Jesus. Thus, none of the students in this study had truly absorbed this kind of relativistic way of dealing with difference. More likely, those inclined to an open and interesting way of encountering difference seemed not to feel the need to participate superficially in that discourse. 
An open and rewarding way of dealing with difference related particularly to such interactions in which religious and cultural difference is not ignored but recognised and communicated. The students spoke, for example, of how they compare their religion with that of their Christian friends and marvel at the differences. Furthermore, in discussions with a Christian researcher, these students related how they considered some aspects of Christianity weird and openly pondered upon the relationship between Islam and Christianity. Different influences were not regarded as dangerous but as objects of observation and discussion, as demonstrated by this 18-year-old girl:

I once visited a church, where I was so amazed you know, because it was so different. I kept asking all the time what is that, why does he do that... It's the same when they ask me about Islam and I always ask them when we don't understand some things they do.

This student was regarded as the most religious and knowledgeable of them all by her classmates. It was interesting to notice that these students, who had received the most extensive education on Islam, were not inclined to regard equality as sameness but more often as related to the ideal of respecting the religious freedom of the individual. In this way, the ways of dealing with difference that were regarded as open and encountering in this study seemed to be related to a concept of tolerance grounded on an Islamic framework. This difference-affirming understanding of equality did not require a departure from their self-understanding of religious tradition: tolerance based on religious freedom was presented in the classroom as an Islamic ideal and as the "will of God." Even though they did not consider it possible to change their religious views, these students regarded it as their religious duty to "treat all people the same despite the differences." Thus, a strong religious identity could be paired with respect and recognition of difference when religious tradition functioned as a resource for tolerance. These students had learned the importance of tolerance and respect from liberal and postmodern discourses, but had interpreted these values in an Islamic framework. In this way, their Muslim identities could align with liberal values.

\section{Discussion}

Most Muslim students were balancing between various ideals of tolerance. The ideals of not regarding difference as an issue and dealing with it in a conformist way can be interpreted as implications of the liberalist educational discourse. The liberal pressure towards inclusiveness led the students to concentrate on commonalities. However, these ideals had to be negotiated with life experiences related to problems caused by difference as well as the need to guard religious identities and group boundaries. Ideals from the postmodern educational discourse could be seen in the students' way of declaring diversity as enrichment, but this ideal had only been superficially internalised and negotiated with the perception that religious difference was a threat due to the exclusivist and universalist nature of religious tradition.
This situation of overlapping and competing discourses on difference in contemporary multicultural societies is the context in which students nowadays are developing their religious identities. Despite the particular and contextdependent nature of the negotiations observed in this study, they can be interpreted as reflections of wider societal negotiations concerning multiculturalism. Even though the ideals of recognizing and celebrating difference have become more prominent, multicultural policies are often still grounded on liberal premises. Furthermore, even though religious minorities, such as European Muslims, criticize these liberal principles, at the same time they defend their own rights through these self same liberal discourses [42]. In this way, different norms of dealing with difference are being mixed and negotiated. In this kind of situation, in order to create educational models that are able to promote peaceful coexistence and take into account the true challenges of dealing with difference, it is important to pay attention to the negotiations that are constantly going on in the lifeworlds of students. These kinds of negotiations that are being undertaken by young Muslims in the West, caused by the conflicting pressures from religious tradition and a liberal worldview, might also lead to unwanted results. There are signs of increasing anti-westernism as well as religious radicalization among immigrant students [43].

The observations of this study demonstrated the difficulties of dealing with religious difference in liberal and postmodern frameworks: the contemporary ideals of dealing with difference based on individualism, relativism, and inclusivism could be absorbed in the case of differences regarded as cultural conventions, but they had to be negotiated in the case of difference related to the truths and norms of religious tradition. In liberal and postmodernist discourses, religion is regarded as subordinate to culture, and considering religions in the framework of cultural relativism puts pressure on religions to protect their authenticity as the repositories of a universal truth transcending culture, which leads to a process of deculturation. In this process, the clash between cultures becomes a clash between culture and religion, and barriers are built between believers and nonbelievers, between those embracing new cultural paradigms and those holding on to religious selfunderstanding as the universal truth transcending culture [39]. These ideas of universality in religions and the sacred nature of religious identification explain why social boundaries linked to religion can be more clear-cut and harder to cross than ethnic boundaries $[29,44]$. In other words, the most difficult clash might not be between different cultures but between inclusivists and exclusivists: intolerance towards those holding exclusivist truth-claims is increasing [14].

The students of this study were young, and the outcomes of their negotiations unknown. However, as there are examples of this kind of negotiation leading to defensive fundamentalist reactions, and as the school seems to make a difference in terms of the students' religious attitudes (see [5]), attention should be paid to the implications of different educational discourses on difference: education on tolerance should not require the students' detachment from their 
self-understanding of their religious or cultural tradition. Thus, in order to recognise the complexities in dealing with religious difference and the multidimensionality of tolerance, it is also important to preserve the legitimacy of religious discourse in school, at least in the context of religious education. Furthermore, more research is needed about young people from different backgrounds and the cultural and ideological sources affecting their ways of dealing with difference. It would also be important to find out where their negotiations between different ideals of tolerance lead them.

\section{References}

[1] B. R. Johnson et al., "A systematic review of the religiosity and delinquency literature," Journal of Contemporary Criminal Justice, no. 1, pp. 32-52, 2000.

[2] L. E. Pickering and A. T. Vazsonyi, "Does family process mediate the effect of religiosity on adolescent deviance?: revisiting the notion of spuriousness," Criminal Justice and Behavior, vol. 39, no. 1, pp. 97-118, 2010.

[3] H. Streib, "Does religious cognition facilitate or prevent xenophobia and violence in adolescents?" CIRRuS Research Reports 4, 2010.

[4] B. Flunger and H. G. Ziebertz, "Intercultural identityreligion, values, in-group and out-group attitudes," Journal of Empirical Theology, vol. 23, no. 1, pp. 1-28, 2010.

[5] M. Verkuyten and J. Thijs, "Religious group relations among Christian, Muslim and nonreligious early adolescents in the Netherlands," Journal of Early Adolescence, vol. 30, no. 1, pp. 27-49, 2010.

[6] G. Afdal, "The Maze of tolerance," in International Handbook of Inter-Religious Education, Part Two, K. Engerbretson et al., Ed., pp. 598-615, Springer, Dordrecht, The Netherlands, 2010.

[7] A. Wright, Religion, Education and Post-Modernity, RoutledgeFalmer, London, UK, 2004.

[8] G. Afdal, Tolerance and Curriculum, Waxmann, Münster, Germany, 2006.

[9] J. M. Halstead, "Liberal values and liberal education," in Values in Education and Education in Values, J. M. Halstead and M. J. Taylor, Eds., pp. 17-28, The Falmer Press, London, UK, 1996.

[10] B. Parekh, Rethinking Multiculturalism. Cultural Diversity and Political Theory, Palgrave Macmillan, Basingstoke, UK, 2006.

[11] T. Modood, Multiculturalism and Integration: Struggling with Confusions, accept pluralism 7th Framework Programme Project, European University Institute, Robert Schuman Centre for Advanced Studies, 2011.

[12] N. M. Stolzenberg, "He drew a circle that shut me out': assimilation, indoctrination, and the paradox of a liberal education," Harvard Law Review, vol. 106, no. 3, pp. 581-667, 1993.

[13] R. Jackson, Rethinking Religious Education and Plurality: Issues in Diversity and Pedagogy, RoutledgeFarmer, London, UK, 2004.

[14] G. Bertram-Troost et al., "European comparison: dialogue and conflict," in Encountering Religious Pluralism in School and Society: A Qualitative Study of Teenage Perspectives in Europe, G. Thorsten Knauth et al., Ed., pp. 405-412, Waxmann, Münster, Germany, 2008.

[15] B. J. Cook, "Islamic versus Western conceptions of education: reflections on Egypt," International Review of Education, vol. 45, no. 3-4, pp. 339-357, 1999.
[16] J. Waardenburg, "Islam in a world of diverse faiths-a historian's view," in Islam and Inter-Faith Relations, P. SchmidtLeukel and L. Ridgeon, Eds., SCM Press, London, UK, 2007.

[17] I. Kalin, "Sources of tolerance and intolerance in Islam," in Religious Tolerance in World Religions, J. Neusner and D. B. Chilton, Eds., Templeton Foundation Press, West Cnoshohocken, Pa, USA, 2008.

[18] F. Schweitzer, "Religious individualization: new challenges to education for tolerance," British Journal of Religious Education, vol. 29, no. 1, pp. 89-100, 2007.

[19] S. Bectovic, "Studying Muslims and constructing Islamic identity," Ethnic and Racial Studies, vol. 34, no. 7, pp. 11201133, 2011.

[20] T. Sakaranaho, Religious Freedom, Multiculturalism, Islam: Cross-Reading Finland and Ireland, Brill, Leiden, The Netherlands, 2006.

[21] T. Martikainen, "Finland," in Yearbook of Muslims in Europe, J. S. Nielsen et al., Ed., pp. 117-126, Brill, Leiden, The Netherlands, 2009.

[22] P. Saukkonen and M. Pyykkonen, "Cultural policy and cultural diversity in Finland," International Journal of Cultural Policy, vol. 14, no. 1, pp. 49-63, 2008.

[23] Finnish National Board of Education, National Core Curriculum for Basic Education, Opetushallitus, Helsinki, Finland, 2004.

[24] T. Gordon, J. Holland, and E. Lahelma, "Ethnographic research in educational settings," in Handbook of Ethnography, P. Atkinson et al., Ed., pp. 188-203, Sage, London, UK, 2007.

[25] D. Foley and A. Valenzuela, "Critical ethnography: the politics of collaboration," in The Sage Handbook of Qualitative Research, N. K. Denzin and Y. S. Lincoln, Eds., pp. 217-234, Sage Publications, Thousand Oaks, Calif, USA, 2005.

[26] P. Norris and R. Inglehart, "Islamic culture and democracy: testing the "clash of civilizations" thesis," Comparative Sociology, vol. 1, no. 3-4, pp. 235-264, 2002.

[27] H. Tajfel and J. C. Turner, "The social identity theory of intergroup behaviour," in Psychology of Intergroup Relations, S. Worchel and W. G. Austin, Eds., Nelson-Hall, Chicago, Ill, USA, 1986.

[28] 'Developing students' willingness to encounter differenceteachers practices in Islamic education," in New Perspectives on Religious and Spiritual Education, T. Van Der Zee and T. Lovat, Eds., Waxmann Publishers, Münster, Germany, 2012.

[29] J. Jacobson, "Religion and ethnicity: dual and alternative sources of identity among young British Pakistanis," Ethnic and Racial Studies, vol. 20, no. 2, pp. 238-256, 1997.

[30] A. Mummendey and M. Wenzel, "Social discrimination and tolerance in intergroup relations: reactions to intergroup difference," Personality and Social Psychology Review, vol. 3, no. 2, pp. 158-174, 1999.

[31] J. F. Dovidio, S. L. Gaertner, and T. Saguy, "Commonality and the complexity of gweg social attitudes and social change," Personality and Social Psychology Review, vol. 13, no. 1, pp. 320, 2009.

[32] L. M. Jackson and B. Hunsberger, "An intergroup perspective on religion and prejudice," Journal for the Scientific Study of Religion, vol. 38, no. 4, pp. 509-523, 1999.

[33] M. B. Brewer, "The psychology of prejudice: ingroup love or outgroup hate?" Journal of Social Issues, vol. 55, no. 3, pp. 429444, 1999.

[34] C. Jacobsen, "The quest for authenticity: islamization amongst Muslim youth in Norway," in European Muslims and the Secular State, J. Cesari and S. McLoughlin, Eds., pp. 155-168, Ashgate, Aldershot, UK, 2005. 
[35] W. A. J. Meijer, Tradition and Future of Islamic Education, Waxmann, Münster, Germany, 2009.

[36] T. G. Jensen, "Context, focus and new perspectives in the study of Muslim religiosity," Ethnic and Racial Studies, vol. 34, no. 7, pp. 1152-1167, 2011.

[37] S. Østberg, "Norwegian-Pakistani adolescents. Negotiating religion, gender, ethnicity and social boundaries," Nordic Journal of Youth Research, vol. 11, no. 2, pp. 161-181, 2003.

[38] N. Fadil, "Individualizing faith, individualizing identity: Islam and young Muslim women in Belgium," in European Muslims and the Secular State, J. Cesari and S. McLoughlin, Eds., pp. 143-154, Ashgate, Aldershot, UK, 2005.

[39] O. Roy, Holy Ignorance. When Religion and Culture Part Ways, Hurst \& Company, London, UK, 2010.

[40] J. R. Seul, "'Ours is the way of God': religion, identity, and intergroup conflict," Journal of Peace Research, vol. 36, no. 5, pp. 553-569, 1999.

[41] M. J. Bennett, "A developmental approach to training for intercultural sensitivity," International Journal of Intercultural Relations, vol. 10, no. 2, pp. 179-196, 1986.

[42] T. Modood, "Muslims and the Politics of Difference," Political Quarterly, vol. 74, pp. 100-115, 2003.

[43] S. Niyozov, "Teachers and teaching islam and muslims in pluralistic societies: claims, misunderstandings, and responses," Journal of International Migration and Integration, vol. 11, no. 1, pp. 23-40, 2010.

[44] C. Mitchell, "The religious content of ethnic identities," Sociology, vol. 40, no. 6, pp. 1135-1152, 2006. 


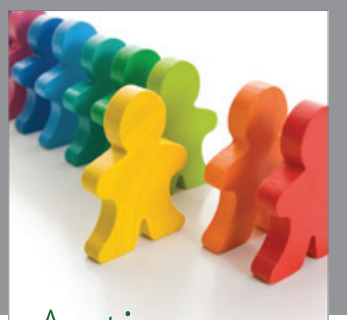

Autism

Research and Treatment
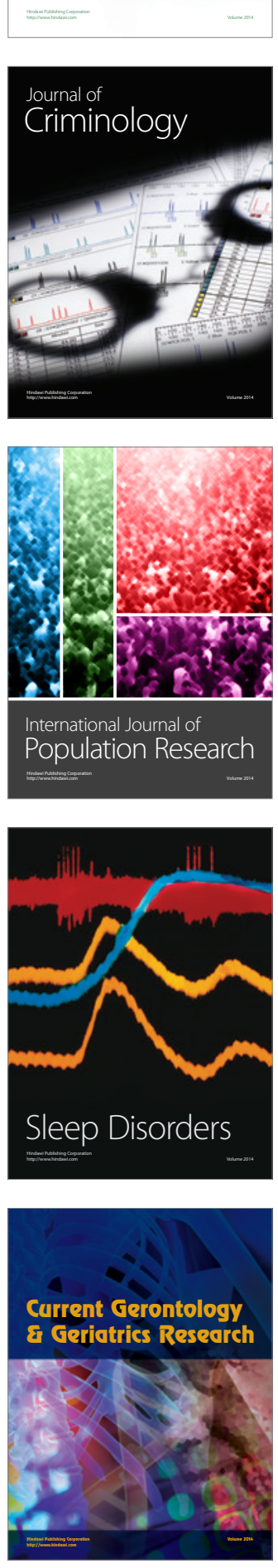
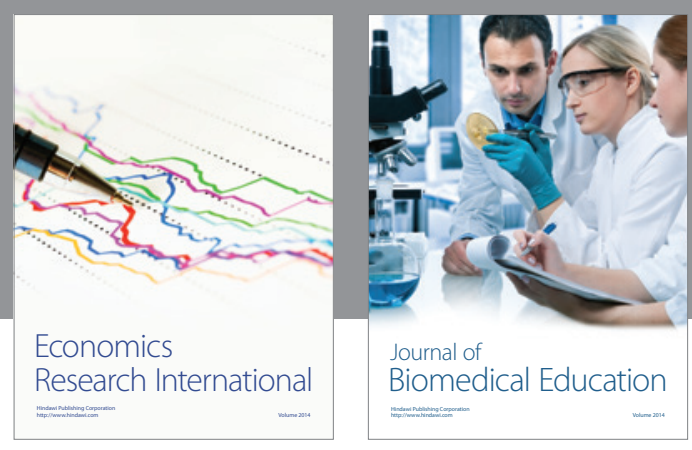

Journal of

Biomedical Education

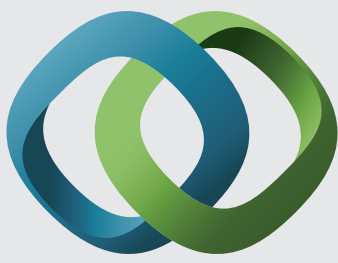

\section{Hindawi}

Submit your manuscripts at

http://www.hindawi.com
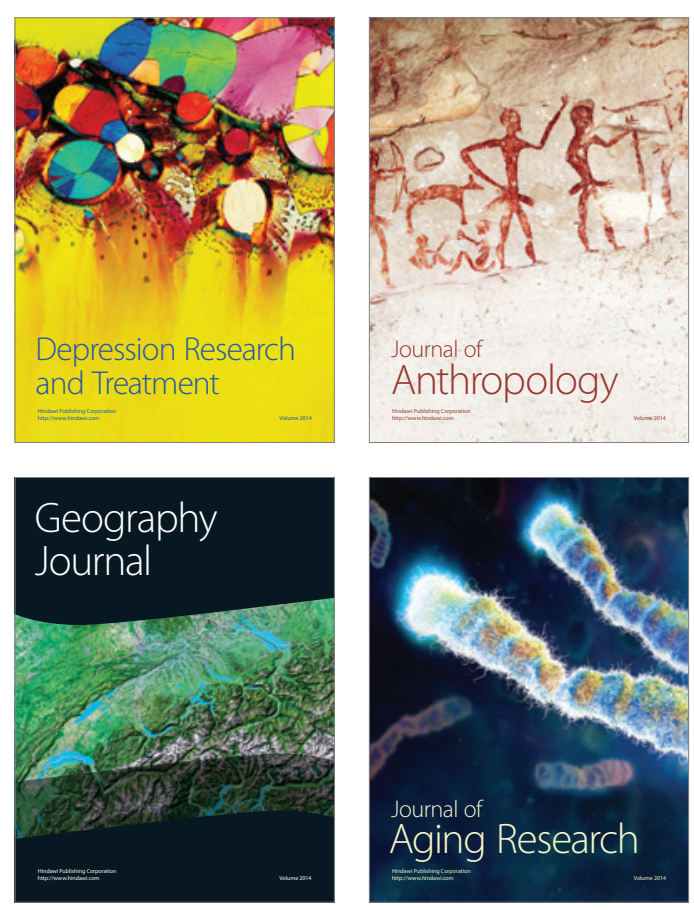

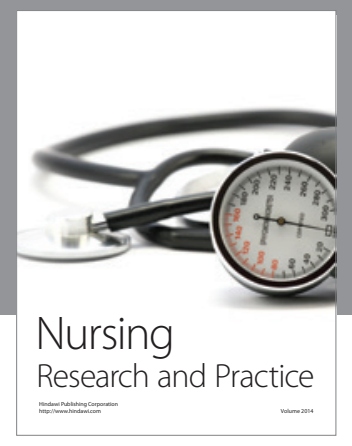

Nursing

Research and Practice

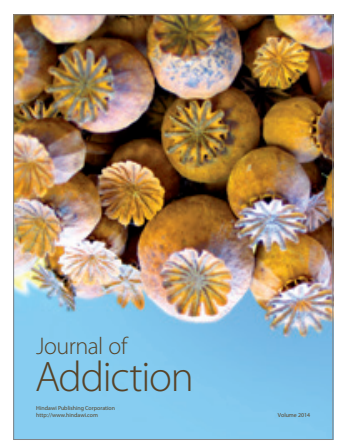

Child Development

Research

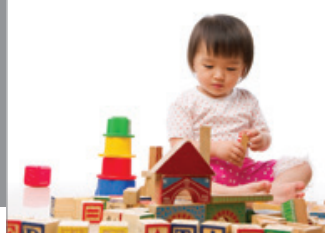

迥
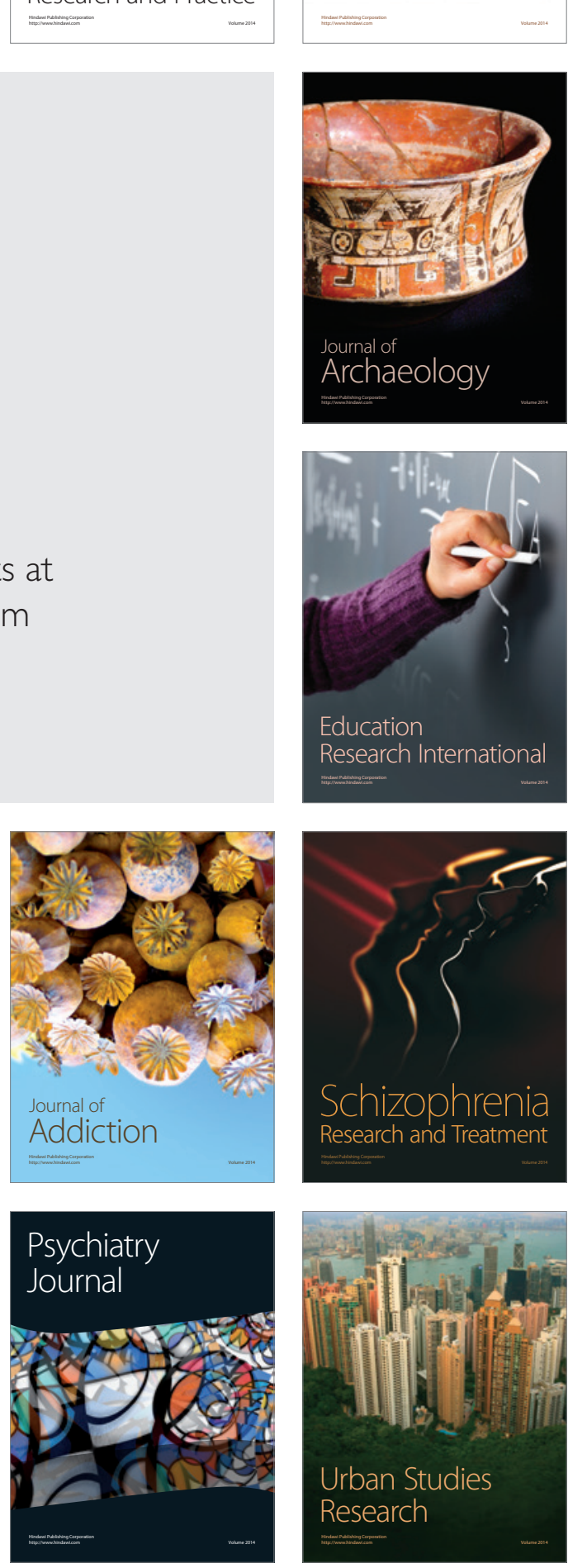